\title{
Correction: Parental offending and children's emergency department presentations in New South Wales, Australia
}

Whitten T, Green MJ, Laurens KR, et al. Parental offending and children's emergency department presentations in New South Wales, Australia. J Epidemiol Community Health 2019;73:832-838.

The surname of the fifth author on this paper is misspelt. The correct spelling is Harris.

(c) Author(s) (or their employer(s)) 2020. No commercial re-use. See rights and permissions. Published by BMJ.

J Epidemiol Community Health 2020;74:488. doi:10.1136/jech-2019-212392corr1

(A) Check for updates 